\title{
Exploratory study of quality and excellence approaches and continuous improvement from the perspective of new institutionalism ${ }^{*}$
}

Karmen Kern Pipan, Boštjan Gomišček, Janez Mayer ${ }^{* *}$

This paper is based on the findings of empirical research conducted in 110 Slovenian companies. Using statistical methods, we examine the effect of the EFQM Excellence Model on the institutionalization of total quality management (TQM) tools and approaches, as well as financial results to motivate TQM implementation. Within the whole group of companies, special attention was paid to the results of applicants for the Slovenian Business Excellence Prize (SBEP), which were compared with other companies. The SBEP group showed better results compared with the other companies with regards to benchmarking, peer assessment, participation in quality and excellence awards, knowledge sharing, self-assessments and financial results.

Dieser Artikel basiert auf den Ergebnissen einer empirischen Untersuchung in 110 Slowenischen Unternehmen. Durch die Anwendung statistischer Methoden untersuchten wir die Wirkung des EFQM Excellence Modells auf die Institutionalisierung der Total Quality Management (TQM) - Werkzeuge und Ansätze sowie finanzielle Ergebnisse, um eine Umsetzung des TQM zu motivieren. Innerhalb der gesamten Gruppe von Unternehmen wurde besonderes Augenmerk auf die Ergebnisse der Bewerber für den Slowenischen Business Exzellenz Preis (SBEP) gerichtet. Die SBEP Gruppe zeigte bessere Resultate bezüglich Benchmarking, Peer-Beurteilung, Teilnahme am Wettbewerb für die Qualität und Exzellenz Preise, Stimulation des Wissenstransfers, Selbstbewertung und finanziellen Ergebnissen.

Keywords: total quality management, quality and excellence award, EFQM Excellence Model, institutional theory, continuous improvement

\footnotetext{
Manuscript received: 19.07.11, accepted: 14.04.12 (2 revisions)

** Karmen Kern Pipan, Ph. D., Metrology Institute of Republic Slovenia (MIRS), Ljubljana, Republic of Slovenia. Main research areas: quality and business excellence management. Corresponding address: karmen.kern.pipan@t-2.net, karmen.kern-pipan@gov.si

Boštjan Gomišček, Ph. D., Associate Professor, University of Maribor, Faculty of Organizational Sciences, Kranj, Republic of Slovenia. Main research areas: quality management.

Janez Mayer, Ph. D., Assistant Professor, University of Maribor, Faculty of Organizational Sciences, Kranj, Republic of Slovenia. Main research areas: organizational behavior and creativity.
} 


\section{Introduction}

The main paradigm of new institutionalism in organizational theory is that organizations aiming to improve their legitimacy and survival prospects have to institutionalize structures, techniques and practices that conform to the mandate of the institutional environment (Meyer/Rowan 1977; Powell/DiMaggio 1991; Beck/Walgenbach 2009). Reviews of empirical work supporting this paradigm reveal, however, that there are still open issues related to the positive effects of the adoption of institutionalized structures, techniques and practices on organizations and financial results. Some authors studied issues related to the diffusion and adoption of institutionalized structures, techniques and practices (Tolbert/Zucker 1983; Beck/Walgenbach 2005); impacts on the institutional and task environments on organizational performance (Oliver 1997); adaptation to changing institutional contexts (Karhunen 2008); the effects of ISO 9000 certification on resource inflow (Beck/Walgenbach 2009) and financial results (Staw/Epstein 2000). However, very little research has been conducted from the viewpoint of the institutional context and an organization's adaptation to institutionalized expectations related to TQM. Beck and Walgenbach (2009) investigated the effects of ISO 9000 certification on resource inflow in German companies and confirmed a positive relationship between them. Furthermore, the results of a survey conducted by Nair and Prajogo (2009) showed the positive effects of internalization of ISO 9000 standards on operational and business performance in Australian companies.

Nevertheless, whether the institutional context affects the implications of a company's adaption to institutionalized expectations in the field of business excellence has not been examined. In our study, we wanted to investigate the effect of the EFQM Excellence Model on the institutionalization of TQM tools, structures, techniques and approaches to motivate TQM implementation and financial results in large Slovenian companies.

In the late 1980s and early 1990s, several countries established programs to recognize the inventive - and effective - quality practices taking place (once again) in Japan, which began promoting quality practices in the 1950s (Vokurka et al. 2000). In the 1990s, the European Foundation for Quality Management (EFQM) and the European Excellence Model were established, while Slovenia, i.e. a part of former Yugoslavia, started restructuring from socialist planning to a market economy. Then, in the mid-1990s, the Slovenian national quality award (SBEP) was founded to promote the development, quality and competitiveness of Slovenian companies.

In recent decades, national quality awards (based on excellence models) have already become an institutionalized practice throughout the world (Calingo 2002; Mavroidis et al. 2007). Therefore, the adoption of the EFQM Excellence Model should, in general, increase the legitimacy of a company, and companies applying for the award should be more successful in obtaining the resources they 
need to be productive than companies that are not applying for the award. However, the competitive advantage of adopting the EFQM Excellence Model also depends on the institutional context in which a company operates.

\section{Business excellence models and awards - institutionalized structured techniques}

In order to gain competitive advantage, companies promote continuous improvement by institutionalizing different tools, approaches and techniques, with the aim of stimulating successful business performance and encouraging technological development. National quality awards have been established with the aim of supporting the systematic implementation of continuous improvement and TQM utilization in organizations. In the EU countries, the EEA, based on the EFQM Excellence Model, has become most widespread model in recent decades. In the so-called East European countries (the Czech Republic, Estonia, Hungary, Latvia, Lithuania, Slovakia and Slovenia) quality awards have been developed and supported (financed and managed) by the government. (An exception is Poland, where the quality award is privately funded.) In Austria, Belgium, Cyprus, Denmark, France, Germany, Greece, Ireland, Luxembourg, the Netherlands, Portugal, Spain, Sweden and the UK, the awards are privately funded and managed. Since business initiatives were started in East European countries in the 1990s, governments have promoted and supported the first steps towards business excellence models in their attempt to improve their national competitiveness (Mavroidis et al. 2007). Similarly, in Slovenia the SBEP was established in 1998 following the example of the EEA and national awards of other EU Member Countries with the full support of the government. Various professional organizations, such as associations of managers, quality experts, standardization bodies, consultant companies as well as business schools have also been important promoters of the award. Beck and Walgenbach (2005) reported the strong promotion of ISO 9000 standards in Germany, with a number of articles presented in proceedings and published in the media, related especially to better exporting opportunities for Western countries. A similar situation was in Slovenia, where many articles were published emphasizing the benefits of the EFQM Excellence Model in terms of providing better business opportunities for companies dealing with foreign markets.

Many studies have confirmed a positive impact of the institutionalization of different quality management techniques and practices in organizations. Some authors studied the effects related to the implementation of different TQM techniques, and indicated the positive effects of: TQM activities on business performance (Mann/Kehoe 1994); open culture, employee empowerment and leadership commitment on TQM (Powell 1995); TQM on strategy formulation, the tactical role of strategy application and deployment (Leonard/Adam 2003); employee motivation, organizational values embedded in culture on quality implementation (Dobosz-Bourne 2006). 
Furthermore, some authors studied the implementation of the ISO 9000 standards and ascertained positive implications: between employees' participation to sales increases and cost reduction (Huarng 1998); on customer and employee relationships (Piskar/Dolinšek 2006); between motivations for adopting and the implementation process (Boiral/Roy 2007), and on the inflow of resources (Beck/Walgenbach 2009).

Some authors also examined the use of business excellence models and reported positive impacts on business performance. The findings published by Hendricks and Singhal (2000) in the USA indicated significantly better financial performance of the award-winning companies in comparison with other companies in the research. Significantly better financial results were found in operating income associated with the effective implementation of TQM in various company characteristics (the company size, the degree of capital intensity, the degree of diversification, the timing of TQM implementation, and the maturity of the program (Hendricks/Singhal 2000)). The results of a study conducted among the award winners in Australia showed a direct link between performance in the award assessments and annual improvement in the bottomline results. Organizations achieving high scores in award assessments were found to be companies with the highest performance across a wide range of indicators, including financial results and productivity. Management aspects, such as senior executive leadership, the analysis and use of data and information, measures of success and planning processes were found to be of particular importance (Hausner 1999). Furthermore, Boutler et al. (2005) conducted a survey in Europe in which the award winners outscored the control group of companies in the shared values, sales, capital expenditure over assets and capital expenditure over sales, higher growth in assets and further reduction in costs over sales. The results of a study done by Haffer and Kristensen (2008) comparing Polish and Danish companies showed that the companies using excellence models achieved better results than the other companies in management, people, systems and results. The lowest results were found in people management in Polish companies in terms of number of proposals for improvement, feedback on employees' proposals for improvement, communication, and people satisfaction (Haffer/Kristensen 2008).

Factors affecting the implementation and institutionalization of TQM in organizations have been debated for decades, but still there is no unique agreement on this concept. Despite these findings, some authors have reported that TQM implementation in organizations did not bring the expected benefits and effects on: organizational performance (Terziovski et al. 1997; Staw/Epstein 2000); financial performance (Sun/Cheng 2002; Watson et al. 2003); management control, procedural problems and customer service (Pivka/Ursič 2002); business process improvement (Ivanović/Majstorović 2006). 
Nevertheless, there are still open issues concerning the excellence model's impact on organizational performance and competitiveness. The extent to which organizational performance can effectively be improved using the business excellence model remains an important issue (Leonard/Adam 2003; Prajogo 2005).

In our opinion, the business excellence models, which are used in all continents, have certainly become a competitive advantage worldwide in recent decades. However, as the use of the business excellence model increasingly becomes a supplier and customer requirement or even marketing approach, it could happen that some organizations would prefer to use it more for their own promotion than to implement continuous improvement, especially the quality and business excellence award winners. In that case, business excellence models (together with business and quality awards) would not only lose their mission, but also lead to a decline, rather than represent a holistic leadership tool supporting continuous improvement in organizations.

\section{The hypotheses}

In this study, we analyse the effect of the EFQM Excellence Model on the institutionalization of techniques for the implementation of TQM; investing financial and human resources for stimulating continuous improvement; management implications for the TQM process and the financial results in large Slovenian companies. The main argument of new institutionalism is that in order to improve their legitimacy and survival prospects, organizations have to institutionalize the structures, techniques and practices that conform to the institutional environment (Meyer/Rowan 1977; DiMaggio/Powell 1983; Beck/Walgenbach 2009). Empirical studies on the effects of the adoption of institutionalized TQM tools and approaches and their impacts on organizational performance are rare. Our study deals not only with the implication of the EFQM Excellence Model for financial data of the companies under study but also with other aspects related to the use of different approaches, tools and techniques stimulating TQM implementation.

The aim of this study is also to establish some of the main features of the companies that have introduced a systematically institutionalized business excellence model (by applying for SBEP), and to compare them with a group of "top Slovenian companies" and a randomly chosen "control" group of companies. The purpose of this research is also to contribute to a broader understanding and knowledge of institutionalized approaches and techniques for stimulating continuous improvement and quality management in organizations, based on the use of the EFQM Excellence Model, in order to rethink the decision to participate in national excellence awards.

The results of a long-term study conducted by Peters and Waterman (1982) among successful companies in the USA showed that productivity through 
people was one of the important attributes of excellent and innovative companies. Therefore, we expect a positive impact of the SBEP application (using EFQM Excellence Model) on investing financial and human resources for stimulating continuous improvement.

H1: Companies that have applied for SBEP allocate more financial and human resources for stimulating continuous improvement than companies that have not applied for SBEP.

The findings of a study performed by Pervaiz (1998) among British companies showed that innovation and employees were the crucial elements of business philosophy in successful innovative organizations. Therefore, we expect a positive impact of the SBEP application (using the EFQM Excellence Model) on the implementation of approaches supporting knowledge and innovativeness in the companies.

H2: Companies that have applied for SBEP use more TQM tools related to approaches encouraging employee knowledge sharing and innovativeness than companies that have not applied for SBEP.

Furthermore, Robinson and Schroeder (2004), when studying successful companies in USA and Japan, stressed the importance of employee ideas and innovativeness for a systematic introduction of TQM in excellent organizations. Therefore, we expect a positive impact of the SBEP application (using the EFQM Excellence Model) on supporting employee proposals for improvement in the companies.

H3: Companies that have applied for SBEP realize more proposals for improvement per employee than companies that have not applied for SBEP.

Furthermore, Leonard and McAdam (2002) argued that management used business excellence models as the standard framework (mapping organizational change activities such as ISO 9000 and Investors in People) in terms of achieving business improvement. According to Van der Wiele et al. (2000a), organizations successfully used self-assessment against quality award criteria for learning and training. Therefore, we expect a positive impact of the SBEP application on approaches for encouraging continuous improvement in the companies.

H4: Companies that have applied for SBEP use more approaches for the identification of information on TQM (such as internet, trainings, employees participating as auditors/assessors, best practice exchange) than companies that have not applied for SBEP.

Van der Wiele et al. (2000b), studying the use of ISO standards and excellence models in the organizations, indicated that self-assessment required the involvement of all managers linked with each activity in the organization at every level of the hierarchy. Furthermore, Tutuncu and Kucukusta (2007) 
conducted a study among Turkish companies and found a strong relationship between organizational commitment and business excellence. Therefore, we expect a positive impact of the SBEP application (using the EFQM Excellence Model) on management implications related to TQM implementation.

H5: Companies that have applied for SBEP use more managerial implications for TQM process than companies that have not applied for SBEP.

Our research is further important in the light of the research findings of several authors dealing with the positive financial performance of the winners of quality and excellence awards (Hendricks/Singhal 2000; Hausner 1999; Boutler et al. 2005). Therefore, we expect applying for SBEP to impact positively on business results.

H6: Companies that have applied for SBEP (using the EFQM Excellence Model) have better financial results than companies that have not applied for SBEP.

Similar research in the field of excellence examining non-financial and financial aspects from the viewpoint of institutional theory has not been performed in Slovenia. We believe that the systematic use of the excellence model in terms of implementation and integration in daily business provides the basis for its institutionalization. Since all SBEP applicants follow the same "excellence concept" through using self-assessment, external assessment, benchmarking, best practice exchange and participation in quality conferences, we expect "excellence behaviour" to be spread among the SBEP applicants as opposed to the other companies included in the study. A new approach in our study is also the comparison between all companies who applied for the national award, randomly chosen control companies, and an additionally introduced the group of top companies, which are regarded as most successful according to their net profit in Slovenia.

\section{The research methodology}

After more than a decade of the SBEP's existence in Slovenia, the participation and the use of excellence models has not yet reached a satisfactory level in comparison with other developed countries. Moreover, the results of the comparisons between the SBEP and EEA applicants in terms of scores achieved have shown that the EEA applicants outscore the SBEP applicants significantly (by an average of 150 to 200 points out of 1000 possible); the highest difference is found in relation with Leadership (22 points), and People - Results and Customer - Results (23 points) (Kern Pipan 2010). An answer to this dilemma could be found in the definition of business excellence that implies exceptional performance that constantly exceeds the expectations of stakeholders by achieving sustainable balanced results. In the global environment, the requirements for achieving business excellence are significantly higher when 
compared to the national level. Therefore, the results of the Slovenian companies (SBEP Group) as compared to the EEA applicants do not show superiority in most cases. There are, however, some exceptions of successful Slovenian companies (past SBEP winners) that operate on the global market and that have also demonstrated their excellence by achieving the level of EEA Finalist or Prize Winner in the previous years.

The organizational field in which we conducted our study was composed of large Slovenian companies (with more than 250 employees). The studied sample of the survey contained three different groups of companies: a group of Slovenian companies, chosen according to their highest net profit based on the AJPES database (the "Top Group"); the second group was randomly chosen from the $\mathrm{CCI}^{2}$ list (the "Control Group"); and the third group consisted of all large companies, i.e. applicants taking part in SBEP (the "SBEP Group"). The main steps used in the research procedure followed the basic scientific approach described in literature, including collection, review and study of theory in the field of quality, identification of the research question, conceptual assumptions, collection, analysis and interpretation of data. The survey instrument was pilot tested among ten representatives of the Slovenian academic sphere and more than twenty representatives of professionals, i.e. managers from the SBEP assessors and jurors pool. The pilot results were used to improve the clarity and readability of the questionnaire. Data for the study were collected in 2007, according to the plan presented in Table 1 .

\section{Table 1: Data collection plan}

\begin{tabular}{|l|l|}
\hline $\begin{array}{l}\text { Statistical population in the } \\
\text { sample }\end{array}$ & large companies in Slovenia \\
\hline $\begin{array}{l}\text { Sample frame and } \\
\text { procedure }\end{array}$ & $\begin{array}{l}500 \text { companies from the population: } \\
- \text { Top Group; top Slovenian companies (according to the } \\
\text { highest net profit) from the AJPES list } \\
\text { - Control Group; randomly chosen companies from the CCI } \\
\text { list } \\
- \text { SBEP Group; all past SBEP applicants from the MIRS list } \\
\text { between 1998 and 2006 }\end{array}$ \\
\hline $\begin{array}{l}\text { Sample size and response } \\
\text { rate }\end{array}$ & $\begin{array}{l}- \text { achieved 110 sample units } \\
-22 \% \text { response rate } \\
- \text { Top Group (48), Control Group (39) and SBEP Group } \\
\text { (23) }\end{array}$ \\
\hline
\end{tabular}

\footnotetext{
${ }^{1}$ The Agency of the Republic of Slovenia for Public Legal Records and Related Services (AJPES) is an indispensable primary source of official public and other information on business entities in Slovenia (www.ajpes.si).

${ }^{2}$ Chamber of Commerce and Industry of Slovenia (CCI) (http://www.gzs.si/slo/).
} 


\begin{tabular}{|l|l|}
\hline Questionnaires answered by & $\begin{array}{l}\text { - heads of organizational units } 53.64 \% \\
\text { - employees from the quality department } 14.55 \% \\
\text { - general manager } 13.64 \% \\
\text { - employees from the human resource department } 2.73 \% \\
-15.46 \% \text { did not specify their position }\end{array}$ \\
\hline Research instrument & - structured questionnaire \\
\hline Data collection method & $\begin{array}{l}\text { - postal and e-mail delivery of questionnaire } \\
\text { - supported by telephone contacts }\end{array}$ \\
\hline Data processing methods & $\begin{array}{l}\text { - statistical processing using SPSS v.15 } \\
\text { - interpretation of questionnaire responses } \\
\text { - confirmation or rejection of research question }\end{array}$ \\
\hline
\end{tabular}

The structure of respondent companies: $31 \%$ with fewer than 250 employees, $34 \%$ between 251 and 500 employees, 28\% between 501 and 1500 employees, and 7\% above 1500 employees. The questionnaire was composed of open questions and questions using a six-point scale ranging from 0 points to 5 points (0 - approach/tool not known/and not used, 5 - most often used/most important). The questionnaire was divided into 12 main issues: general data on the company; financial and human resources invested in continuous improvement; continuous improvement tools; measurement and rewarding of employees for continuous improvement, realization and rewarding proposals for improvement, number of proposals for improvement; TQM approaches; TQM recognition schemes; identification of TQM changes; and management implications for TQM process. Additionally, we calculated the financial indicators Return on Assets (ROA) and Return on Equity (ROE) (Kern Pipan 2010). ${ }^{3}$

Data were analyzed using ANOVA to conduct significance tests of variance and to reduce the number of items as well as to study the main statistically important differences between the sample means of the studied groups of companies (Kern Pipan et al. 2011). Using ANOVA, the variability of the variable is split into two parts. The first reflects the general variability of respondents within the groups (MSw: mean square within groups) and the second represents the differences between the groups attributable to the treatment effect (MSB: mean square between groups). MSw estimates of the average respondent variability on the dependent variable within a treatment group are based on deviations of individual scores from their respective group means. MSB estimates the variability of the treatment group means on the dependent variable; it is based on deviations of the group means from the overall grand mean of all scores. The ratio of MSB to MSw is F statistics, and as such measures how much variability can be attributed to the different treatment versus the variability expected from random sampling. Large values of the F statistics lead to a rejection of the null

\footnotetext{
${ }^{3}$ The questionnaire and the full list of all items used in this study showing F statistics and calculated p-values could be sent on demand by corresponding author.
} 
hypothesis of no difference between means across groups. Calculation of $\mathrm{F}$ statistics was done to test the significance among differences of the perceived characteristics of different groups of companies, as follows:

F statistics $=$ MSB $/$ MSW

where:

MSB - mean square between groups,

MSW - mean square within groups.

To test our hypotheses, we validated ANOVA results using the Post Hoc Test (Bonferonni) to investigate the differences in the mean values among all three studied subgroups of companies and to select the items suitable for further research. Post Hoc Tests do not use a single contrast, but instead test for differences among all possible combinations of groups (Hair et al. 2006).

In items for which statistical significance between the mean values was found, the reliability was further tested using Cronbach's alpha. In the summary, 20 items were suitable for further research (Cronbach's alpha $>0.7$ ) (Hair et al. 2006).

\section{Results}

The obtained results presented in Table 2 confirmed significant statistical differences in favour of the SBEP Group as compared to the two other groups of companies. The findings show that in sections (A) "Human resources invested in continuous improvement", (B) "Financial resources invested in continuous improvement" and (C) "Employee trainings invested in continuous improvement", the SBEP Group of companies obtained mainly higher results as compared to the other two groups within the items constituting this section (number of employees for QM, HR and R\&D, financial resources for continuous improvement, education, days of training for TQM, innovativeness, HRM and leadership). However, no statistical significance $(\mathrm{p}<0.05)$ between the group mean values was confirmed for either section. Based on these findings, we can conclude that the SBEP application has no impact on investment in financial and human resources for stimulating continuous improvement in the studied companies, and therefore, H1 cannot be supported.

Table 2 shows further that the SBEP Group of companies outscored the other two groups $(p<0.05)$ in the use of (D) "Continuous improvement tools", containing the following items: techniques for creative thinking; non-material recognition of proposals for improvement; employee career promotion related to proposed improvement; collaboration with professional institutions and universities; collaboration with consultant companies; conducting interviews with employees; and electronic system for collecting ideas for improvement. These findings indicate that the SBEP application (and use of the EFQM model) 
has a positive impact on the implementation of approaches supporting knowledge and innovativeness in the studied companies, which supports $\mathrm{H} 2$.

The results in section (E) "Measurement and rewarding of employees for improvement", also show that the SBEP Group obtained higher results in the item "internal comparison of proposals for improvement (with financial evaluation)". Although in general, the results in the other two items (monitoring of proposals for improvement (with and without financial evaluation) and internal comparison of proposals for improvement) indicate higher results for the SBEP Group as compared to the other studied companies, no statistical significance between the group mean values was confirmed. Similar results can be found in the complete sections (F) "Rewarding proposals for improvement" (average percentage of realization of proposals for improvement, average net savings based on realized proposals for improvement, average net reward for realized proposals for improvement), and (G) "Realization of improvement" (number of proposals for improvement, number of employees proposing improvement). Based on these findings, we can conclude that the SBEP application has a positive impact on internal comparison of proposals for improvement (with financial evaluation), but does not have a considerable impact on supporting proposals for improvement in the studied companies, and therefore $\mathrm{H} 3$ can only be party supported.

In section $(\mathrm{H})$ "TQM approaches", the results show that the SBEP Group of companies outscored the other two groups $(p<0.05)$ in the use of self-assessment according to the EFQM Excellence Model; presentation of TQM system at conferences; benchmarking with best in class; and the Balanced Scorecard. Although in general, the results of other items constituting this section (peer assessments, 20 Keys, Six Sigma, Investors In People, mutual audits with suppliers/customers, ISO 9001 audits, ISO 17025 audits, process indicators, systems for collecting and rewarding proposals for improvement) indicate higher results for the SBEP Group as compared to the other studied companies, no statistical significance between the group mean values was confirmed. These findings indicate that the SBEP application has a positive impact on selfassessment, presentation at TQM conferences, benchmarking with best in class and Balanced Scorecard, but does not have a considerable impact on other TQM approaches in the studied companies, which partly supports $\mathrm{H} 4$.

In section (I) "TQM recognition schemes", the findings indicate that the SBEP Group of companies outperformed the other two groups $(p<0.05)$ in the importance of winning national excellence awards (SBEP), winning European excellence awards (EEA), participation in quality award competitions, participation in SBEP projects, and participation in projects of the Chamber of Commerce and Industry for introduction of continuous improvement and innovativeness into the organization. Nevertheless, the results of other items consisting this section (importance of ISO 9001 certification, ISO 17020, 17025 
accreditation) generally indicate higher results for the SBEP Group compared with other studied companies, but no statistical significance between the group mean values was confirmed. Based on these findings, we conclude that companies that apply for SBEP estimate a positive impact of their participating in award procedures for introduction of continuous improvement and innovativeness into the organization, but do not considerably affect other approaches for identification of TQM information in the studied companies, which partly supports $\mathrm{H} 4$.

Furthermore, the results in section (J) "Identification of TQM news" indicated that the SBEP Group outscored the other two groups $(p<0.05)$ in employee participation as auditors/ assessors and participation in quality award competitions. Although, in general, the results of other items describing this section (reading literature and internet news, participation in seminars and trainings, participation in conferences and workshops, peer assessment) indicate higher results for the SBEP Group as compared to the other studied companies, no statistical significance between the group mean values was confirmed. These findings imply that the SBEP application has a positive impact on employee participation as auditors/assessors and on participation in quality award competitions, but does not have a considerable impact on other approaches for identification of TQM information in the studied companies, which partly supports $\mathrm{H} 4$.

In section (K) "Managerial implications for TQM process", the SBEP Group generally obtained higher results compared to the other two groups in the items constituting this section (related to the impact of leadership style, value system, employee satisfaction, personal annual interview, regular meetings of leaders with employees, open communication and informal meetings regarding the process of continuous improvement). However, no statistical significance $(p<0.05)$ between the group mean values was confirmed for the complete section. Based on these findings, we can conclude that the SBEP application has no impact on managerial implications related to TQM implementation in the studied companies, and therefore H5 cannot be supported.

Furthermore, in section (L) "Financial indicators" our findings show that the Top Group of companies possesses higher levels of results $(\mathrm{p}<0.05)$ on ROA (7.17), followed by the SBEP Group (5.83) and the Control Group (0.26). In the case of ROE, the SBEP Group obtained the highest result (16.11), followed by the Top Group (13.92) and the Control Group (2.01). However, no statistical significance for ROE between the group mean values was confirmed. These findings implicate that the SBEP application has positive impacts on business results in the studied companies, and we can partly support H6. 
Table 2: ANOVA with statistically significant differences between the group means of the three studied groups of companies Top Group (TG), Control Group (CG), SBEP Group (SBEP) $(p<0.05)$ and Cronbach's Alpha if Item Deleted $(C A)$

\begin{tabular}{|c|c|c|c|c|c|}
\hline Items & TG & $\mathbf{C G}$ & SBEP & $\mathbf{C A}$ & Sig. \\
\hline \multicolumn{6}{|l|}{ D. Continuous improvement tools } \\
\hline $\begin{array}{l}\text { Techniques for creative thinking of employees } \\
\text { (7b) }\end{array}$ & 1.250 & 1.667 & 2.913 & 0.786 & 0.000 \\
\hline $\begin{array}{l}\text { Non-material recognition of proposals for } \\
\text { improvement }(7 \mathrm{~d})\end{array}$ & 1.542 & 1.436 & 2.913 & 0.794 & 0.002 \\
\hline $\begin{array}{l}\text { Employee career promotion is related to proposed } \\
\text { improvement }(7 \mathrm{e})\end{array}$ & 1.625 & 1.462 & 2.478 & 0.791 & 0.038 \\
\hline $\begin{array}{l}\text { Collaboration with professional institutions and } \\
\text { universities to encourage best practices ( } 7 \mathrm{f})\end{array}$ & 1.833 & 1.410 & 2.609 & 0.787 & 0.023 \\
\hline $\begin{array}{l}\text { Collaboration with consultant companies to } \\
\text { encourage improvement }(7 \mathrm{~g})\end{array}$ & 1.625 & 1.077 & 2.130 & 0.789 & 0.027 \\
\hline Conducting interview with employees (7h) & 0.938 & 0.846 & 1.739 & 0.793 & 0.016 \\
\hline $\begin{array}{l}\text { Electronic system for collecting ideas for } \\
\text { improvement }(7 \mathrm{j})\end{array}$ & 2.000 & 1.231 & 2.391 & 0.796 & 0.041 \\
\hline \multicolumn{6}{|l|}{$\begin{array}{l}\text { E. Measurement and rewarding of employees } \\
\text { for improvement }\end{array}$} \\
\hline $\begin{array}{l}\text { Internal comparison of ideas for improvement } \\
\text { (with financial evaluation) ( } 8 \mathrm{~d} \text { ) }\end{array}$ & 0.875 & 1.179 & 1.957 & 0.794 & 0.022 \\
\hline \multicolumn{6}{|l|}{ H. TQM approaches } \\
\hline $\begin{array}{l}\text { Conducting self-assessment using the EFQM } \\
\text { Excellence Model (11d) }\end{array}$ & 0.708 & 0.538 & 3.130 & 0.788 & 0.000 \\
\hline Presentation of TQM system at conferences (11f) & 2.083 & 1.949 & 3.174 & 0.790 & 0.003 \\
\hline Benchmarking with best in class (11g) & 2.667 & 2.385 & 3.391 & 0.795 & 0.020 \\
\hline Balanced Scorecard (11h) & 1.542 & 1.487 & 2.957 & 0.787 & 0.002 \\
\hline \multicolumn{6}{|l|}{ I. TQM recognition schemes } \\
\hline $\begin{array}{l}\text { Winning the national excellence award (SBEP) } \\
\text { (13c) }\end{array}$ & 0.542 & 0.564 & 2.087 & 0.790 & 0.000 \\
\hline $\begin{array}{l}\text { Winning the European excellence award (EEA) } \\
\text { (13d) }\end{array}$ & 0.396 & 0.436 & 1.087 & 0.796 & 0.008 \\
\hline Participation in quality award competitions (13e) & 0.771 & 0.487 & 2.087 & 0.790 & 0.000 \\
\hline Participation in the SBEP projects (13f) & 0.583 & 0.487 & 3.174 & 0.786 & 0.000 \\
\hline $\begin{array}{l}\text { Participation in the projects of the Chamber of } \\
\text { Commerce and Industry }(13 \mathrm{j})\end{array}$ & 1.208 & 0.821 & 1.826 & 0.792 & 0.037 \\
\hline
\end{tabular}




\begin{tabular}{|l|l|l|l|l|l|}
\hline J. Identification of TQM news & & & & & \\
\hline $\begin{array}{l}\text { Employee participation as auditors / assessors } \\
(14 \mathrm{e})\end{array}$ & 1.458 & 1.256 & 3.000 & 0.793 & 0.000 \\
\hline Participation in quality award competitions (14f) & 0.917 & 0.744 & 2.261 & 0.795 & 0.000 \\
\hline L. Financial indicators & & & & & \\
\hline Return on Assets & 7.169 & 0.263 & 5.835 & 0.898 & 0.000 \\
\hline
\end{tabular}

\section{Discussion and implications}

This paper presents the main findings of a survey performed among large companies in Slovenia, with the main goal of studying important differences among three groups of companies in relation to the impact of the EFQM Excellence Model on the institutionalization of TQM tools, structures, techniques and approaches as well as financial results to motivate TQM implementation. The results of the study suggest that companies benefit from complying with institutionalized expectations and implementing the EFQM Excellence Model mainly in the non-financial results, e.g. the use of approaches for stimulating knowledge sharing and innovativeness, measurement of proposals for improvement, different TQM approaches for promoting continuous improvement, participation in TQM recognition schemes, approaches for upgrading the knowledge on TQM news. The financial results of the SBEP Group exceeded those of the Control Group, but not those of the Top Group of companies. Based on the results of our study, we can conclude that the main benefits from complying with institutionalized expectations and implementing the EFQM Excellence Model in the companies can be found in the non-financial rather than financial results.

Another interesting implication of our study is that the adoption of expectations from the institutional environment increases the legitimacy and survival prospects of the company, which confirms the findings of several authors in the field of institutional theory (Powell/DiMaggio 1991; Barley/Tolbert 1997; Karhunen 2008); it may also have a positive effect on the implementation of the TQM tools, techniques and financial results, which confirms the findings of Beck and Walgenbach (2009). However, bearing in mind that the findings of our research partly confirmed H6 by showing that the ROA result for the SBEP Group (5.83) was higher than the average of all three groups (4.42), it outscored also the Control Group (0.26), but the result of the Top Group of companies was even higher (7.17). Nevertheless, it is very likely that the companies that applied for the national excellence award, and were publicly announced as finalists or winners, have strengthened their competitive advantage as being an example of excellence, as compared to "ordinary" companies. In contrast, being announced as an SBEP applicant implies a kind of "proven implementation" of TQM, which may influence stakeholders' perception of the company (performance, 
trust and reputation) in the environment, regardless of the actual degree of implementation of TQM in the company. The SBEP companies that have taken part in the award process and thereby implemented the EFQM Excellence Model, have indeed proved significant advantage over both other groups of companies under examination in a number of studied items (see Table 2). We can conclude that a positive impact of the SBEP application (using the EFQM Excellence Model) was found in the systematic use and institutionalization of the approaches supporting management of proposals for improvement and innovativeness, such as implementation of non-material recognition, measurement of proposals for improvement, which confirms the findings of other authors who investigated companies using excellence principles (Leonard/McAdam 2003, Robinson/Schroeder 2004), and reporting the positive effects on employee ideas and innovativeness for a systematic introduction of TQM. Furthermore, a positive impact of the SBEP application (using the EFQM Excellence Model) was found in the systematic use and institutionalization of the approaches for encouraging continuous improvement in the companies, such as the use of best practices, knowledge sharing with academia, professionals and consultants, benchmarking, peer assessment, selfassessment and award assessments, which confirms the findings of other authors emphasizing the importance of using business excellence models in terms of institutionalization of the approaches for encouraging continuous improvement and learning in the companies (Van der Wiele et al. 2000a; Vokurka et al. 2000).

Some of the above-stated results in favour of the SBEP Group (use of best practices, presentation of TQM system at conferences, self-assessment, participation in quality and excellence awards, and employee participation as auditors or assessors) could have been expected. DiMaggio and Powel (1983) as well as Beck and Walgenbach (2009) argue that organizations operate in the fields of other organizations that influence their behaviour, especially in the case of gained institutionalized structures. From the perspective of institutional theory, companies applying for an excellence award (SBEP) are part of an organizational field, where they are influenced by excellent organizations (winners) and expected to follow the example and behave in a certain way. Therefore some of the results gained by the SBEP companies could be explained as a part of the "excellence behaviour" deriving from the institutionalization of the award methodology (use of benchmarking, best practices, self-assessment, and presentation of the TQM system at conferences, employee participation as auditors or assessors, and participation in quality and excellence awards). In general, the SBEP Group possesses higher mean values as compared to the other groups of companies. However, the findings show some items where the SBEP companies who applied the EFQM Excellence Model possess a higher value than the group mean, but do not have a significant advantage over the other two groups of companies under survey in items such as: financial and human resources invested in continuous improvement; partly the use of continuous 
improvement tools (use of material recognition); the number, realization and rewarding of proposals for improvement; partly the TQM approaches and recognition schemes (ISO 9001, ISO 17025, 20 Keys, Six Sigma, process indicators); partly identification of the TQM news (use of literature and internet, participating in trainings); and management implications for the TQM process (leadership, values, employee satisfaction, communication). These results are interesting, especially as there is no significant difference between the mean values of the studied companies in the use of material recognition for improvement, implementation of ISO standards and management implications for the TQM process. It is known from the literature that material recognition for improvement is a rather inefficient method, and that non-material recognition, leadership and organizational culture are argued as the most important factors for successful TQM implementation (Peters/Waterman 1982; Imai 1996; Robinson/Schroeder 2004). The findings of our research partly confirmed these arguments and showed the impact of the EFQM Excellence Model on the institutionalization of the techniques for promoting continuous improvement through a higher mean value with statistical significance for non-material recognition related to improvement in favour of the SBEP Group as compared to the other studied companies. Nevertheless, the findings of this study did not show any statistical difference for managerial implications for TQM in favour of the SBEP Group as compared to other studied companies, and did not confirm the impact of the EFQM Excellence Model on the institutionalization of leadership, values, employee satisfaction and communication related to the TQM process. We believe this might be the crucial issue for companies (such as Slovenian ones) operating in Eastern Europe in terms of further development and gaining comparative advantage, especially for a breakthrough in global markets, and could provide a relevant question for a future research. Similar findings were reported by Haffer and Kristensen (2008), who compared the implications of excellence initiatives in Danish and Polish companies and found significantly better results for Danish companies in terms of managerial implications and people management in comparison with Polish companies (which are still dealing with the transition period, similar to that in Slovenia). The results from comparing the SBEP and EEA average scores showed that EEA outscored SBEP significantly (in average by 150 to 200 points out of 1000), the highest difference could be found in criteria describing Leadership, People Results and Customer Results (Kern Pipan 2010). It is not clear how far the Slovenian companies are developed in terms of TQM introduction in general, but the average results in SBEP are significantly lower than those achieved in EEA. Although some exceptional Slovenian companies have succeeded in reaching the level of EEA finalists, other Slovenian companies do not demonstrate an "excellent" level of performance as measured by the EFQM Model scores. 
In recent years, a number of studies have examined several important aspects related to the implementation of excellence models in companies (e.g. Hendricks/Singhal 2000, Hausner 1999, Robinson/Schroeder 2004 and Haffer/Kristensen 2008). At the same time, there are few authors who investigated the positive effects of institutionalization related to TQM (Beck/ Walgenbach 2005, Karhunen 2008, Nair/Prajogo 2009). However, the results of our study confirmed their findings and add an important piece to the overall mosaic of knowledge underlying the use of excellence models and the institutionalization of approaches for encouraging continuous improvement in companies. The positive effects of implementing excellence models into the companies were confirmed as regards the use and the institutionalization of nonmaterial motivation for proposals for improvement, the use of best practices, knowledge sharing, benchmarking, peer assessment, self-assessment and award assessments. We have ascertained that, in the context of systematic implementation of TQM, it is important for policy-makers and company managers to pursue the institutionalization of excellence models by focusing on the TQM tools and approaches that support the continuous improvement process, people motivation and knowledge sharing in the companies.

The limitations of the study might be as follow: the first limitation is derived from the size of the sample and its subgroups (Top Group (48), Control Group (39) and SBEP Group (23)), in which the latter group is rather limited. However, we do not believe that this limitation had a strong impact on the results of the study. Another limitation to be considered is the actual level of business excellence and competitiveness of Slovenian companies compared to the international market globally. There are rare examples of Slovenian companies who have achieved results at the European level (EFQM Excellence Award). There could be a gap between excellent companies applying at the European level and the SBEP Group.

Future studies should thus focus on the question as to whether there is an effect of TQM institutionalization related to survival chances, reputation and legitimacy, including both the fields in which excellent companies operate and the fields in which economically less successful companies operate globally. Further, future research could focus on the implementation of quality and business excellence in the public sector (e.g. health, education) in Slovenia and abroad. This would contribute to a better understanding and wider use of the EFQM Excellence Model in the public sector, and help improve the effectiveness and efficiency of the public sector. Our study examined the effects of adoption of business excellence principles on TQM approaches and financial results in Slovenian companies. However, a question still remains open and needs to be examined in a future research - it is related to the impact of the adoption of other institutionalized techniques and practices and their implications for organizational performance in the private and public sectors. 


\section{Acknowledgements}

The authors wish to acknowledge the support of MIRS during conducting the empirical study.

\section{References}

Barley, S.R./Tolbert, P.S. (1997): Institutionalization and Structuration: Studying the Links between Action and Institution, in: Organization Studies, 18, 1, 93-117.

Beck, N./Walgenbach, P. (2005): Technical Efficiency of Adaption to Institutionalized Expectations? The Adoption of ISO 9000 Standards in the German Mechanical Industry, in: Organization Studies, 26, 6, 841-866.

Beck, N./Walgenbach, P. (2009): The economic consequences of ISO 9000 Certification in East and West German firms in the mechanical engineering industry, in: Journal for East European Management Studies, 14, 2, 166-185.

Boiral, O./Roy, M.J. (2007): ISO 9000: Integration Rationales and Organizational Impacts, in: International Journal of Operations \& Production Management, 27, 2, 226-247.

Boutler, L./Bendell, T./Abas, H./Dalghaard, J./Singhal, V. (2005): Report on EFQM and BQF funded Study into the Impact of the Effective Implementation of Organizational Excellence Strategies on Key Performance Results. Centre of Quality Excellence: The University of Leicester.

Calingo, L.M.R. (2002): National Quality and Business Excellence Awards: Mapping the Field and Prospects for Asia, in: Report of the Symposium on Quality and Business Excellence Awards, Asian Productivity Organization, Fiji, 3-23.

DiMaggio, P.J./Powell, W.W. (1983): The Iron Cage Revisited: Institutional Isomorphism and Collective Rationality in Organizational Fields, in: American Sociological Review, 48, 2, 147-160.

Dobosz-Bourne, D. (2006): Reverse diffusion of quality: Evidence from general motors UK and Poland, in: Journal for East European Management Studies, 11, 3, 224-226.

Haffer, R./Kristensen, K. (2008): Developing versus developed companies in Business Excellence initiatives, in: Total Quality Management, 19, 7-8, 763-775.

Hair, J.F./Black, W.C./Babin, B.J./Anderson, R.E./Tatham, R.L. (2006): Multivariate Data Analysis. Sixth Edition, Pearson, Prentice Hall: New Jersey.

Hausner, A. (1999): Business success and ABEF evaluation results: on the nexus between manufacturing results and frameworks for business excellence, University of Wollongong, http://ro.uow.edu.au/theses/1573 (retrieved on 2009 May 05).

Hendricks, K.B./Singhal,V.R. (2000): Firm Characteristics, Total Quality Management, and Financial Performance, in: Journal of Operations Management, 238, 1-17.

Huarng, F. (1998): Integrating ISO 9000 with TQM spirits: A survey, in: Industrial Management \& Data Systems, 98, 8, 373-379.

Imai, M. (1996): Kaizen, Der Schluessel zum Erfolg der Japaner im Wettbewerb: Berlin, Frankfurt am Main, Ullstein.

Ivanović, M.D./Majstorović, V.D. (2006): Model developed for the assessment of quality management level in management system, The TQM Magazine, 18, 4, 410-426. 
Karhunen, P. (2008): Toward convergence in the St. Petersburg hotel industry through the lens of institutional theory, in: Journal for East European Management Studies, 13, 2, 106-128.

Kern Pipan, K. (2010): The Impact of Human Capital and Continuous Improvement on Business Excellence in Organization, Doctoral Dissertation, Faculty of Organizational Sciences, University of Maribor: Slovenia.

Kern Pipan, K./Gomišček, B./Kljajić, M./Jesenko, M. (2011): An empirical study on comparing total quality management (TQM) items on national quality award applicants in Slovenia, in: African Journal of Business Management, Academic Journals, 5, 33, 12829-12840.

Leonard, R./Adam, D. (2002): The Role of Business Excellence Model in Operational and Strategic Decision Making, in: Management Decision, 40, 1, 17-25.

Leonard, R./Adam, D. (2003): An Evaluative Framework for TQM Dynamics in Organizations, in: International Journal of Operations \& Production Management, 23, 6, 652-677.

Mann, R./Kehoe, D. (1994): An Evaluation of the Effects of Quality Improvement Activities on Business Performance, in: International Journal of Quality \& Reliability Management, 11, 4, 29-44.

Mavroidis, V./Toliopoulou, S./Agoritsas, C. (2007): A compatative analysis and review of national quality awards in Europe, Development of critical success factors, in: The TQM Magazine, 19, 5, 454-467.

Meyer, J.W./Rowan, B. (1977): Institutionalized Organizations: Formal Structure as Myth and ceremony, in: American Journal of Sociology, 83, 2, 340-363.

Nair, A./Prajogo, D. (2009): Internalisation of ISO 9000 standards: the antecedent role offunctionalist and institutionalist drivers and performance implications, in: International Journal of Production Research, 47, 16, 4545-4568.

Oliver, C. (1997): Sustainable Competitive Advantage: Combining Institutional and Resource-Based Views, in: Strategic Management Journal, 1, 18, 697-713.

Pervaiz, K.A. (1998): Benchmarking innovation best practice, in: Benchmarking: An International Journal, 5, 1, 45-58.

Peters, T.J./Waterman, R.H. (1982): In Search of Excellence: Harper \& Row Publishers, Inc., New York.

Piskar, F./Dolinšek, S. (2006): Implementation of the ISO 9001: from QMS to business model, in: Industrial Management \& Data Systems, 106, 9, 1333-1343.

Pivka, M./Uršič, D. (2002): The impact of ISO 9001 certification process on Slovenian companies, in: Journal for East European Management Studies, 7, 1, 27-45.

Powell, T.C. (1995): Total Quality Management as Competitive Advantage: A Review and Empirical Study, in: Strategic Management Journal, 16, 15-37.

Powell W.W./DiMaggio, P.J. (1991): The New Institutionalism in Organizational Analysis: The University of Chicago Press.

Prajogo, D.I. (2005): The comparative analysis of TQM practices and quality performance between manufacturing and service firms, in: International Journal of Service Industry Management, 16, 3, 217-228. 
Robinson, A./Schroeder, D.M. (2004): Ideas Are Free: How the Idea Revolution is Liberating People and Transforming Organizations, Berret-Koehler Publishers, Inc., San Francisco.

Staw, B.M./Epstein, L.D. (2000): What bandwagons bring: Effects of popular management techniques on corporate performance, reputation, and CEO pay, in: Administrative Science Quarterly, 45, 523-556.

Sun, H./Cheng, T.K. (2002): Comparing Reasons, Practices and Effects of ISO 9000 Certification and TQM Implementation in Norwegian SMEs and Large Firms, in: International Small Business Journal November, 20, 4, 421-442.

Terziovski, M./Samson, D./Dow, D. (1997): The business value of quality management systems certification, evidence from Australia and New Zealand, in: Journal of Operations Management, 15, 1, 1-18.

Tolbert, P.S./Zucker, L.G. (1983): Institutional sources of change in the formal structure of organizations: The diffusion of civil service reform, 1880-1935, in: Administrative Science Quarterly, 28, 22-39.

Tutuncu, O./Kucukusta, D. (2007): Relationship between Organizational Commitment and EFQM Business Excellence Model: A Study on Turkish Quality Award Winners, in: Total Quality Management, 18, 10, 1083-1096.

Vokurka, R.J./Stadnig, G.L./Brazeal, J. (2000): A Comparative Analysis of National and Regional Quality Awards, in: Quality Progress, 3, 88, 41-49.

Van der Wiele, T./Brown, A./Millen, R./Whelan, D. (2000a): Improvement in organizational performance and self-assessment practices by selected American firms, in: Quality Management Journal 7, 4, 8-22.

Van der Wiele, T./Dale, B.G./Wiilams, A.R.T. (2000b): ISO 9000 Series and Excellence Models: Fad to Fashion to Fit, in: Journal of General Management, 25, 3, 1-17.

Watson, J./Kober, R./Ng, J./Subramaniam, T. (2003): The Impact of TQM Adoption on SME Financial Performance, in: Proceedings of 16th Annual Conference of Small Enterprise Association of Australia and New Zealand, 1-9. 